(C) The Author(s), 2022. Published by Cambridge University Press on behalf of The Hegel Society of Great Britain. This is an Open Access article, distributed under the terms of the Creative Commons Attribution licence (https://creativecommons.org/licenses/by/4.0/), which permits unrestricted re-use, distribution, and reproduction in any medium, provided the original work is properly cited.

\title{
Roman Courage and Constitution in Hegel's Philosophy of Right
}

\author{
George Hristov
}

\begin{abstract}
This article argues that the citizens of Hegel's state cannot maintain themselves as politically free because they are susceptible to mutual enslavement. I demonstrate this by focusing on the Roman republican background of Hegel's constitution, the potential trajectory of its dissolution and the accompanying means of its cyclical fortification through courage. Hegel, by integrating aspects of the Roman mixed constitution also adopts the idea of decadence within his conception of civil society. After locating the source of decadence in the contractual relations of peace and the bourgeois inability to overcome the fear of death, I go on to argue that war for Hegel provides a theatre where freedom may be regenerated through courage. However, I also show that modern wars do not provide sufficient means of perpetuating Hegel's constitution. To demonstrate this, I distinguish three forms of war: colonial, limited and total war, arguing that only the latter offers a solution to decay of political disposition and loss of freedom, but that - by being itself susceptible to decadence - it cannot salvage Hegel's state from dissolution and reduction to contractual relations.
\end{abstract}

\section{Polybius, Hegel and the mixed constitution}

The ancient idea of the cyclical change of regimes, or anacyclosis, formulated by Polybius in his Histories, is founded on the notion that the transfer of power from fathers to sons necessarily introduces decay into the fabric of society. Descendants corrupt the political system, forcing its correction through regime change, propelling an eternal cycle.

According to the theory of Polybius, the original regime on the scene of history is monarchy, raised by 'perfect savages' (Polybius 1979: 289), representing a primitive centralization of power. This state acts as a prelude to the emergence of kingship or the rule of the one who is just (1979: 279). From this point onwards, 


\section{Courage and Constitution}

the cycle takes its decadent trajectory, the descendant of the king degenerating into a tyrant, instituting the rule of the one who is incapable of ruling himself (1979: 285). The tyrant must be replaced by the virtuous few around him, the aristocrats. But 'here again when children inherited this position of authority from their fathers', they 'abandoned themselves' to excess (1979: 285). The offspring of aristocrats become oligarchs, instituting the rule of the few incompetent rich (1979: 285). This state finally must be corrected by the virtuous democrats. But when democracy 'falls into the hands of the grandchildren of its founders, they have become so accustomed to freedom and equality that they no longer value them' (1979: 287). The democratic offspring institute an ochlocracy or the rule of a headless mob (1979: 287). From the mob, which returns into the original state of 'perfect savages' (1979: 289), arises yet again a primitive monarch, or the individual around whom a new state may be founded, recommencing the cycle.

Legitimate authority is always restored by being relegated to a broader pool of rulers: from the one to the fem, and from the few to all. These passages, Polybius argues, are a matter of necessity, not of probability. Consequently, there is no possibility to avert fate and influence the procession of the regimes. However, in Polybius's view the decline can be decelerated by 'mixing' the three good regimes. Instead of regimes correcting each other through succession - those that follow to serve as solution to the corruption of the preceding ones-they would instead mutually check and balance each other by constituting one single constitution (Polybius 1979: 291). It was the Romans, according to Polybius, who had Providence (tyche) on their side, because through a 'long period of struggle and hardship' (Wallbank 2002: 206) they would come to adopt a measure that could decelerate decline. The three good regimes-kingship, aristocracy and democracy-were combined by the Romans in order to stave off their degenerate forms and thus prolong the life of the state. Polybius attributed the endurance and predominance of the Roman Republic to its mixed constitutional nature, since 'this peculiar form of constitution possesses an irresistible power of attaining every object upon which it is resolved' (Polybius 1979: 309-11).

Renato Cristi, writing on Hegel's monarchy, comments on his resurrection of 'Polybius's idea of status mixtus' in The Philosophy of Right (Cristi 2005: 115). Hegel's adoption of the mixed constitution, he continues, is done by refashioning the 'interior design' (2005: 115) of the ancient model. While for Polybius the purpose of the mixture was to force an 'equilibrium' (2005: 116) between the distinct regimes by making them elements of a single constitution, for Hegel, power is 'monopolized by one center of decision', the monarch (Cristi 1983: 613).

Hegel, guided by Montesquieu, at first adopts Polybius's arrangement in The Philosophy of Right at the level of the political state, or the state as an institution distinct from society. This is done by reformulating the tripartite division of the mixed constitution into the principle of separation of powers between the legislative, the 


\section{George Hristov}

executive and the monarch. But he rejects the principle of 'checks and balances' as the ground of this separation since this would reduce the elements of the political state to relations of 'abstract understanding' and 'mutual limitation' (PR: $\$ 272) .{ }^{1}$ The aim cannot be to 'devise ingenious defences whose efficiency depends merely on corresponding counter-defences' (PR: \$272). Such a view is 'characteristic of the negative understanding and, as far as disposition is concerned, characteristic of the outlook of the rabble' (PR: $\$ 272$ ). Cristi is correct that an 'equilibrium' is not the condition under which the powers of the state are divided for Hegel.

The rejection of such an external criterion is extended to the second level at which Hegel adopts the idea of the mixed constitution. This is the level of the state regarded as society. The background for this broader division is Hegel's own world history, which follows a procession from one who is free, to few who are free, and finally to all who are free ( $P H: 32 / 31$ ), echoing the succession of governments in Polybius. 'The first political form therefore which we observe in History, is Despotism, the second Democracy and Aristocracy, the third Monarchy' (PH: 121/ 134). The regimes correspond to three ages of world-history: despotism to ancient Orient, democracy and aristocracy to Greece and Rome respectively, and monarchy to Christian Europe. ${ }^{2}$ The historical movement for Hegel at first follows Polybius's model, where primitive centralization of power takes place in the Orient. However, instead of converting this power into wise kingship, and from there descending towards licence, Hegel's movement commences with despotic caprice and develops from this point onward in the direction of lawfulness. Through the process of repetition 'that which at first appeared merely a matter of chance and contingency becomes a real and ratified existence' (PH: 332/ 380 ), for not 'abstract and irrational necessity of a blind fate', but the providence of 'reason' is discernible in history (PR: \342). In contrast to old tyche, which still retained the character of a 'fickle and unstable goddess' (Wallbank 2002: 209-10), Hegel's Providence guides contingencies to manifest in the rational necessity of the development of freedom. Although tyche was on Rome's side as it managed to decelerate the turns of the cycle, guiding their rise and expansion based on their constitutional form, in the end, the reversals of Fortune would lead back into it. Spirit, however, commences as despotism but instead of eventually falling back into debauchery, it works its way up through democracy and aristocracy into monarchy, which at the end of history preserves the democratic and aristocratic legacies.

The result of this union is that the monarchic, aristocratic and democratic estates in Hegel's state do not stand for distinct political regimes within an external unity of a common constitution, because all 'political constitutions are one-sided if they cannot sustain within themselves the principle of free subjectivity and are unable to conform to fully developed reason' (PR: \$273A). Polybius's construction is a product of the understanding. The model does not emanate from the principle of the people, but is maintained by mutually antagonistic groups. Rome's 


\section{Courage and Constitution}

development was 'from the very beginning, of violent and artificial, not spontaneous growth' (PH: 301/344) since this state was formed by a 'rabble of all sorts' (PH: 303/346). This is reflected in the long lasting and rigid division between the plebs and the aristocracy. Existing still in an undeveloped condition in which democratic or aristocratic forms are possible', the Roman people could not perceive itself as an 'internally developed and truly organic totality' (PR: \$279). Leo Strauss points to Hegel's reference that the Romans themselves spoke of their origins in terms of violence and fratricide, the killing of one's closest, arguing that this for Hegel 'reveals the character of Rome' - a state forged and maintained through violence (Strauss 2019: 260). Polybius depicts this relation in which each regime is politically armed and turned against the other. Each estate utilizes its political institutions as a weapon. The democratic plebeians constitute the popular assemblies and the tribune of the plebs, who could veto all actions of the senate. The senate in turn is the political arm of the aristocracy, whose decrees constrain the plebs. The executive power compelling these two into common action are the monarchic figures of the consuls, as well as a dictator in time of war and crisis.

Hegel's constitution, on the other hand, is not a mixture of opposed elements, but functions as a 'system of mediation' (PR: $\$ 303 \mathrm{~A})$. The union of the regimes presupposes the people as a single whole through which each regime mediates the others. The democratic element, corresponding to Greece, does not appear as a mass of individual wills as was the case in Athens, but is structured and organized through the mediating function of the estates, the aristocratic element of the government and the unity provided by the monarch. This ensures 'that individuals do not present themselves as a crowd or aggregate, unorganized in their opinions and volition, and do not become a massive power in opposition to the organic state' (PR: \$303A). By acting as a 'mediating organ' (PR: \$302) the modern aristocratic layer of the government is not defined in antithesis to the people as was the case in Rome, but provides 'the mediating function of the organized power of the executive' (PR: \$302) between the monarch and the people. This ensures not only the coherence of the people but also that the monarchic element itself 'does not appear as an isolated extreme — and hence simply as an arbitrary power of domination' (PR: \$302) Finally, the monarch acting from above, and the democratic forces organized in estates from below, ensure that the aristocratic element 'does not adopt the isolated position of an aristocracy', which could use its 'education and skills as arbitrary means of domination' (PR: \$297).

Robbed of their self-sufficiency, the regimes that constitute Hegel's state stand in a mediated relation to each other. Rational union thus presupposes the political disarmament of the social field. The citizens are not organized by rigidly divided orders held together in 'unspiritual unity' (PH: 326/373), and locked in continual political warfare. Hegel's 'citizen' does not signify political activity, but relates primarily to life within the spheres of the family and civil society. The bourgeois are 


\section{George Hristov}

not natural political agents, but appear as citizens only by being family members and workers. They are citizens to the degree that they possess 'political disposition', a form of trust through which the interests of these two spheres are integrated into the common will of the state. In this disposition the bourgeoisie do not live their life 'merely for these particular interests without at the same time directing their will to a universal end' (PR: \$260). However, they live these lives without occupying the institution of the political state itself. Apart from the qualification of bourgeois activity as self-conscious political existence, Hegel's citizens have no political role to play in times of peace. The demos do possess an institution — the parliament-but neither do they participate in this organ nor is it weaponized as a defensive arm against the government, but by sharing the mediating function with it, their members also share a common disposition (PR: \$310).

This principle extends to the government or the aristocracy as well. At first and in distinction to the demos, the members of the government do engage in political activity. The aristocracy is political to a higher degree than the demos, since they do in fact act as agents within the political institutions of the state. But this is only provisionally the case, because Hegel limits their political activity to professional vocation. The members of the government are professional politicians, and the 'objective moment in their vocation [Bestimmung] is knowledge [Erkenntnis] and proof of ability' that through their work and ability 'the needs of the state will be met' (PR: \$291). The aristocratic aspect of the state is subject to the same general division of labour which limits the demos. Both elements of the state are politically engaged as bourgeois, in other words through work, unbinding political activity from warfare by subordinating it to the discipline of civil society.

The only estate that escapes subordination to this commercial discipline is the monarch. Hegel explicitly does not reduce them to a bourgeois. Their position is not attained through choice of vocation, since the monarch appears as a political agent by birth (PR: \$280). Their hereditary nature circumvents work as a condition of citizenship. However, because their position is hereditary, the level of depoliticization of the monarch reaches an even higher degree than that of the demos and the aristocracy. In distinction to the wills of the latter, theirs is merely symbolic. The 'I will' (PR: $\$ 279$ A) they perform affirms the will of the whole as a decision of an individual state, but as such it is a symbol of unity and has no independence.

Cristi is thus correct that the monarch is given higher political status than the other two estates. The regime itself is a monarchy with the sovereign being the only natural political agent. The democratic and aristocratic elements are unified within monarchy (PR: \$279) and thus 'cease to be either democratic or aristocratic' (Cristi 1983: 613). But Hegel does not disregard the division of powers as 'guarantee of public freedom’ (PR: \$272) by giving full reign to the monarch, as Cristi’s Schmittian reading of Hegel would suggest. The default mode of Hegel's presentation of the state is peace, and during peacetime the monarch is no less 


\section{Courage and Constitution}

constrained than the democrats and the aristocrats, being de facto politically disarmed as the other two are. ${ }^{3}$ The sovereign's political independence is cancelled by the mediating effects of the demos and the aristocracy. Hegel's state thus does achieve an equilibrium between the three elements by mutual cancelation of each other's isolated forms. 'General equilibrium' (PR: \$272) between the powers is not an external criterion of the union, but estates being internally unified, they generate a balance through mediation emanating from the principle of the people.

The three estates, consequently, still 'check and balance' each other, preventing themselves from decaying into isolated extremes. However, the corrupt forms of democracy, aristocracy and monarchy are not their degenerate types, but they themselves if they were to appear as isolated and mutually opposed political units. Rational unity of the people presupposes their political disarmament, and their contribution to the life of the state only if they are not what they are. The same principle which applies to the division of the political state is applicable to the state as a whole: 'If the powers [...] attain self-sufficiency $[\ldots]$ the destruction of the state $[\ldots]$ is immediately posited' (PR: $\$ 272)$.

\section{Contract and Hypocrisy}

In distinction to the Republic, which was a state in conflict with itself, engulfed in a perpetual struggle between the orders of citizens, Hegel's state is a mediated totality and a formation of peace. The collapse of the Roman state was brought on by the mounting divisions between the plebs and the aristocracy. Increasingly divided by the extremes of wealth and poverty, they tore the Republic apart. Under the weight of these divisions the 'Roman constitution', Hegel writes, was no longer 'in a condition to be saved by the constitution itself' (PH: 328).

Polybius, who wrote at the time of the Third Punic War, predicted such an outcome, since it was this war that changed the fortunes of the Roman state. After the destruction of Carthage, when Rome eliminated their most formidable enemy, the Republic would inherit the hegemony over the Mediterranean, ushering in an age of peace and decline (Polybius 1968: 369). The mixed constitution, which emerged out of perpetual adversity, was not fit for prolonged peace. Such a regime could function only under the condition that the union was permanently haunted by the fear of the foreign enemy. Fear of defeat provoked unity among the heterogeneous elements, preventing the estates from giving way to their 'aggressive impulse' in relation to each other (Polybius 1979: 311). 'For whenever the menace of some common danger from abroad compels them to act in concord', Polybius observed, 'so great does the strength of the state become $[\ldots]$ as all are zealously competing in devising means of meeting the need of the hour' and 'all are co-operating both in public and in private to the accomplishment of the task 


\section{George Hristov}

which they have set themselves' (1979: 309). With the annihilation of Carthage, the last competitive enemy of Rome, this common fear dissipated.

Hegel traces this fall from the moment when 'tension of virtue' became relaxed and 'no external power confronted' the Republic anymore (PH: 326/ 373). In the Natural Law he quotes Gibbon on the 'long peace' after the war with Carthage introducing the 'slow and secret poison' (NL: 101) into the vitals of the republican state. Not made for peace, the Republic's 'unspiritual unity' was to disintegrate, for it could find no regenerative power in foreign threats anymore. Internal divisions and conflicts became exacerbated under the excesses of spoils of war. The aristocratic senate became a locus of corruption and bribery, while the democratic estate 'was now a mere mob' (PH: 328-29/377). The monarchic element, on the other hand, gave way to 'colossal individualities', who were 'instinctively impelled to restore that political unity which was no longer to be found in men's dispositions' ( $\mathrm{PH}$ : 329/377. Patriotism, the valorous fidelity to the will of the gods and the 'dominant instinct' (PH: 326/373) of Rome, evaporated. Although the citizen's 'personal valor remained' they no longer 'possessed that public courage which is nourished by the love of independence, the sense of national honor, the presence of danger, and the habit of command' (NL: 102).

No such threat of peace presents itself to Hegel's state. External dangers were a necessity for Rome, since the 'uniting bond' of 'social units' amounted to no more than 'abstract universality' (PH: 307/351). Union had to be imposed from outside, because relations within could not attain it themselves. Ancient recognition, grafted onto discrete social units, was determined by an objective will and sundered in its trajectory from the outset. Modern families are not encased in kinship networks and their orders, as a whole they emerge atomized in relation to each other (PR: \$172A). Correspondingly, modern individuals are not confined to rigid social orders, but enter a sphere of recognition as individuals within civil society, which reveals itself to be the engine of atomization. Being subordinate to the processes of civil society, political activity is not rooted in the common discipline of war, which when absent during prolonged peace on the external front, brings ruin on the internal one. In the modern struggle bourgeois must attain their own discipline, since 'each individual, by a process of self-determination, makes himself a member of one of the moments of civil society through his activity, diligence, and skill, and supports himself in this capacity' (PR: \$207). Since modern discipline presupposes an individual's selfconscious activity, political unity may take root within the relations of these individuals.

By basing the state on the principle of rational unity, Hegel aspires to cancel decadence as a matter of cyclical necessity. For Polybius, the union of individual regimes rested on the dispositional nature of the rulers. Bound to objective conditions, where 'subjective freedom is not yet recognized' (NR: \$262A), they were unable to sustain themselves throughout the cycles of history, where they only saw their ruin. The descendants of the king turn into adulterers, who give 'way 


\section{Courage and Constitution}

to their appetites', pursue 'luxury' and lawless 'amours' (Polybius 1979: 283), transforming the whole regime into tyranny. Degenerate aristocrats abandon themselves to 'greed of gain', the 'violation of women' and 'the rape of boys' (1979: 285), debasing the whole state into an oligarchy. Finally, the democratic offspring turn to 'lust for power' and 'thirst for reputation' (1979: 287), setting the state on a course toward ochlocracy. In Hegel's state, on the other hand 'debauchery [on the part of the monarch] can [...] have no effect on the whole' (NR: \$140). The state is not founded on the particular disposition of the monarch as an individual, but on the totality of social relations in which the whole is actually present. Civil society opens a space where individuals can engage in free relations of recognition, thus providing the state with conditions for a unified people. It allows the state to act as a living unity regenerated through the active participation of the free will, dispensing with an externally imposed mythological framework and the 'blind necessity' of fate.

However, although the modern state presupposes the participation of the free will, political authority for Hegel cannot in the last instance rely on relations emerging from it. Civil society does provide the space for a modern people to appear, but taken on its own terms it presents no people at all, but an atomistic aggregation of an 'external state', and a state of 'the understanding' (PR: \$183). Civil society in fact emulates the late Republic by presenting 'ethical life, lost in its extremes', affording a 'spectacle of extravagance and misery, as well as of the physical and ethical corruption common to both' (PR: \185).

Decadence in modernity thus takes root in those very relations which provide the state with a power unprecedented in history. More specifically, the relations of the contract, which constitute civil society and represent 'the true distinctive ground in which freedom has its existence' (PR: \$71) at the same time appear to undermine and stand in contradiction to political freedom. The relations of the contract signify the expression of the subjective will, through which such a will attains its validity. So Hegel writes that only with Hobbes was the state for the first time founded on 'principles which lie within us' (quoted in Riley 1973: 146), namely on the recognition of the free will as the legitimate source of political authority. Yet in Hegel's view, although modern political authority presupposes these relations, it cannot be sustained by them.

The reason for this is that a contract relates individual wills in relation to property. Any union emerging from a contract would be no more than an aggregation of individuals where 'the interest of individuals [der Einzehzen] as such becomes the ultimate end for which they are united' (PR: \$258). If the state were to be founded on the contractual relations of civil society, then its members would be validated 'based on their arbitrary will and opinions, and on their express consent given at their own discretion’ (PR: \$258). The freedom of contractual consent however presupposes caprice. Alan Patten notes that Hegel's rejection of the contract is based on this inadequate conception of freedom. 'Hegel thinks that "giving in" to one's desires 


\section{George Hristov}

and inclinations is no more a case of freedom than is submitting to an authority: both are cases of allowing something external to determine for one what one could think through for oneself' (Patten 2002: 114). Indeed, these two sides—arbitrariness and submission - presuppose each other. Because civil society represents the space where 'all passions surge forth' (PR: \$182) and arbitrariness takes precedence, as a whole it necessitates a system of guarantees and securities (such as in the law courts and the police, PR: \$230) as well as the state itself that presides and dominates over it. Viewed abstractly and as a mere member of civil society, the bourgeois does remain subject to the external necessity of the state.

Hobbes already demonstrates this. The fear of the unknown, which extends to all causes, permeates the bourgeois soul in the natural state. This fear and uncertainty manifest between atomized individuals as mistrust and continual anxiety before violent death at the hands of the other (Hobbes 1998: 84). Consent overcomes this fear by submitting the bourgeois to state authority that provides them with a guarantee of life, security and property. Contract thus serves as a form of trust (1998: 86) which alleviates the arbitrariness and doubts present in bourgeois relations. But as Hobbes himself argued, contract is a form of trust between citizens maintained through the transcendence and the 'awe' commanded by state authority, which must 'tie them by fear of punishment to the performance of their covenants' (1998: 111). The fear before uncertainty and death which is encountered in the natural state comes into service of monarchic authority and its capacity to exact revenge for transgressions against the contract. By mobilizing the natural fear of death, contract founds the state as a guarantee of bourgeois relations.

However, to regard the state as means to 'protect and secure the life, property, and arbitrary will of everyone' would reduce it for Hegel to 'an arrangement dictated by necessity [Not]' (PR: \$270). The state would amount to an external restriction. Such a state would in fact politically validate and formalize the mutual mistrust of the bourgeois. The act of becoming a citizen would become an act of consent and submission to authority out of fear, which seen through the eyes of the ancients, is actually an act performed by a slave. As Patrick Riley notes, Hegel regarded the Leviathan in line with the Roman Empire, as 'perfect despotism' (Riley 1973: 146). The reason for this is that, as Leo Strauss notes, imperial Rome for Hegel represented an aggregation of property owners, a collection of 'mutually repellent social units that can then be held together only by despotic power' (Strauss 2019: 263), as well as their continual fear of death. ${ }^{4}$

Certainly, even in Hegel's state, as a mere member of civil society and bourgeois, the subject remains subordinate to the authority of the state. Civil society requires contractual relations as a form of trust guaranteed by a restrictive and coercive apparatus above (PR: \$230). Although the contract formalizes recognition bonds in relation to property, the doubts and mistrusts that fuel it persist and lead to a situation where each individual in the end remains 'his own end' and 


\section{Courage and Constitution}

makes others into their 'means' (PR: $\$ 182) .^{5}$ The bourgeois, viewed in abstraction, continue to mutually subject each other to their private wills and must thus all be collectively overseen by the coercive apparatuses of the courts and the police and, as mere bourgeois, remain restricted by the external necessity of the state. There can be no political belief or trust in such relations, and fear persists, otherwise there would be no need for 'securities and guarantees' or a contract of any kind.

The only way to prevent the reduction of the state to such a 'guarantee' is to reverse the relationship and repurpose civil society as means of the state. In order to transcend the state as an alienated authority, and prevent its reduction to the relations of civil society, it is necessary for the subject to assume the disposition fostered by political authority. Instead of consenting to living under a state, the bourgeois must allow the will of the state to inhabit their soul. The conflicts between private wills which fuel civil society must, like in ancient times, yet again give way to common discipline. But precisely in this return to antiquity, modernity now reveals the advantages it has over antiquity.

Virtue will now not be imposed on individuals by an objective will. Instead, political disposition presupposes individuals who can assume this will as their own. In as much the bourgeois on their own amount to subjects and means of work, by possessing subjective will they may raise themselves to a level of citizenship the ancients could never achieve. As Hegel remarks, even 'in the beautiful democracy of Athens [...] we can see at once that the Greeks based the ultimate decision on completely external phenomena [Erscheinungen] such as oracles, the entrails of sacrificial animals, and the flight of birds' (PR: \$279). The will of the gods that guided ancient states could never be the same as that of the individual, it always remained obscure and beyond. The subjective will, on the other hand, does not merely serve as a vehicle of the general will, but may completely identify with monarchic power (PR: \$268). Although subjective freedom, in its caprice and propensity toward heteronomy, marks a divergence from old virtue, it also allows for its higher realization. Instead of remaining fragmented under the despotic and divine aristocracy as in Rome, the people can achieve union internally, because the monotheistic will of the state is now in fact the will of each of its members.

This power of modernity, to make political authority and the will of the individual one, raises the interdependence of civil society to the level of rational relations and in Hegel's eyes frees the state from substantial political antagonisms. Contractual, bourgeois relations do persist, but they do not sunder the whole across political, religious and other dimensions, as it was the case with economic conflicts in antiquity. Modern conflicts instead give way to a form of power, which retroactively transforms the atomistic and Hobbesian civil society into an already structured and internally differentiated organism.

Certainly, for Hegel the modern state is not a 'work of art' (PR: \$258) and remains rife with oppositions, such as those between the democratic estate and 


\section{George Hristov}

the government, but in a well constituted state they remain 'superficial', conflicts being about 'specialized and trivial things' as opposed to 'essential elements of the political organism' (PR: §302). Similarly, the aristocracy may be filled with 'factional rivalry over merely subjective interests such as the higher offices of state' (PR: \$302), but being merely subjective, they are of no consequence to the coherence of the whole. These conflicts do 'disfigure' (PR: \$258) the state, but political reconciliation guarantees that the 'affirmative aspect' (PR: \$258) remains undisturbed. The checks between the estates in Hegel aim not at the citizen, but at the bourgeois within the citizen, preventing an estate to posit itself as self-sufficient (PR: \$272). Inner rationality of political relations and the accompanying disposition block subjective, bourgeois induced conflicts, mistrusts and doubts from introducing vices and fragmentation into the constitution of the whole.

The question remains, however, how does the state reproduce the bourgeois into a citizen, in other words, how is the state capable of regenerating itself throughout the generations? Although Hegel presents his state in times of its spiritual dominance, where the citizen is in charge of affairs, he still anticipates that 'in the long run, people become stuck in their ways', that the unity withers away and that 'parts' of the state will grow 'internally hard' (PR: \$324), leading to the very fragmentation and division he aspires to avoid. The subordination of political activity to the discipline of civil society that ensures internal peace also gradually erodes relations of freedom. In other words, decadence is still at work, and the dominance of the citizen remains under threat of being undermined by the bourgeois. Indeed, the very advantage of modernity, contained in the identification of the subjective will with political authority, now presents the state with new depths of decadence.

Writing a century later after the destruction of Carthage, Sallust viewed this event—in line with Polybius's prediction—as the catalyst for Rome's disastrous state of affairs. When the citizen's fear before foreign dangers dissipated, 'self-indulgence and arrogance, attitudes that prosperity loves, took over' (Sallust 2010: 79). Before Carthage was no more, Rome was engaged in an almost perpetual state of war, an age when 'fear of a foreign enemy preserved good political practices' (2010: 79). When peace-'more bitter and cruel than adversity' (2010: 79) — began to reign, hypocrisy slowly crept into the edifices of the Republic:

Ambition forced many men to become liars, to hide one thing in their heart and have something else ready on their tongue, to value friendship and enmity according to convenience, not substance, and to put a good face rather than have a good heart. (Sallust 2010: 15)

At first, hypocrisy 'grew gradually', kept at bay by being 'punished' occasionally, but then, the 'contagion invaded like a plague' (2010: 15), turning everyone-Sallust included (2010: 11) —into a decadent. 


\section{Courage and Constitution}

Hegel's anticipations follow this diagnosis. He at first observes that only during wartime does the 'vanity of temporal things [Dinge] and temporal goods', the bourgeois' apparent renouncement of 'fixed realities' in the name of duty, 'takes on a serious significance' (PR: \$324). 'At other times', in other words during peacetime, they amount to no more than a 'pious phrase' (PR: \$324). Hypocrisy, whereby the bourgeois 'pretends in all external respects to be good, conscientious, pious' (PR: $\$ 140)$ is certainly a threat. Henry Harris shows how already in System of Ethical Life, Hegel makes the principle of 'honesty' (EL: 153) animate the bourgeois in order to prevent their 'decay into hypocrisy and natural hostility' (EL: 69). Already there Hegel distinguishes between inner and outer hypocrisy, the latter corresponding to the observations of Sallust. However, at issue is the former, since 'hypocrisy in its immediate shape has more or less disappeared' (PR: $₫ 140 \mathrm{~A})$. The 'barefaced lie and cloak of goodness has become too transparent not to be seen through' (PR: \$140A). Hypocrisy 'has now assumed' a 'subtler guise' (PR: $\$ 140$ A), whereby the hypocrite does not merely represent their private desires in guise of the common good, but provides their subjective opinion with a force of indominable conviction. In other words, the modern hypocrite does not hide the true 'I' behind a facade, but aspires to 'exalt' the 'I' and elevate it to 'divine status' (PR: $\$ 140 A$ ). As a modern hypocrite 'as soon as I relate myself to something objective, it ceases to exist for me, and so I am poised above an immense void, conjuring up shapes and destroying them' (PR: $\$ 140 \mathrm{~A})$. The hypocrite actually believes in their 'good' inner conviction, 'thoroughly persuaded of its truth', automatically making evil out of 'that of which I am not convinced' (PR: $\$ 140 \mathrm{~A})$. This type of hypocrisy is most evident in fanaticism and it arises 'only in a highly cultivated age in which faith has lost its seriousness' (PR: \$140A). Hegel and Nietzsche are in agreement here. In distinction to Sallust who complained that the Republic was being overrun by hypocrites, Nietzsche is bothered that the few hypocrites he had come across are not even proper ones, but 'actors', who are 'imitating hypocrisy' (Nietzsche 2005: 201). The reason for this is that 'hypocrisy belongs to an age of strong faith' (2005: 200). Romans could turn into proper hypocrites, since they were held together by common belief. After external threats were gone, the fear before military defeat under the eyes of gods evaporated. They continued to imitate ancient virtue, while consciously striving to realize private ends. But since the bourgeois, as Nietzsche argues, belong to an age where hypocrisy has been made into 'innocence' (2005: 216) or rather, a default state of affairs, they perform a second-order imitation, thus remaining 'bonest' (2005: 200) in hypocrisy.

The issue at hand here is that the transcended system of belief that presided over antiquity allowed for a limited, or rather, a classical expression of hypocrisy. When belief evaporated what took place was its imitation. Citizens knew in their hearts they did not believe, but the only point of reference remained the external framework under which they lived for centuries and which now, as Sallust laments, 


\section{George Hristov}

became a shadow of its former self (Sallust 2010: 15). But in modernity, the individual will identifies with political authority itself. The day-to-day frame of reference for the modern will is not transcendent and mythological, but inner and subjective in kind, it does not appear as commonly rooted belief, but as opinion. The danger contained in modern hypocrisy is thus not the imitation of common belief, but more readily the elevation of subjective, arbitrary opinions to that of the general will. This would not be mere imitation of a derelict religion as it was in the late Republic, but the belief in one own's opinion as a measure of the general will.

The correspondence of the private and the public good in Hegel's state is thus not in danger of being disturbed by intentional obfuscation, whereby the private would be malevolently represented in guise of the common, but by the citizens actually believing that their private, subjective opinions are in fact reflections of the general will. In other words, the state would come into danger of privatization at the hands of the bourgeois. Instead of subjective will embodying the general will, the former would seek identification with the latter by taking its own arbitrariness as the measure of the common good.

This would impact the nature of political struggles that inhabit Hegel's state. The 'merely' subjective conflicts, which as long as the rational unity holds, remain 'superficial', would turn 'substantial' (PR: $\$ 302,342)$, because now to the citizens their subjective opinions and desires would appear as emanating from the general will. Bourgeois, contractual relations would penetrate the state, making the general will indistinguishable from opinions in the eyes of their beholders. ${ }^{6}$ The hypothetical negative scenarios that Hegel seeks to avoid would take on a shape of reality, the distinct elements of the state becoming alienated from each other: democracy turning into a 'crowd or aggregate' and 'a massive power in opposition to the organic state' (PR: \$302), the mediating institutions of the political state becoming a tyrannical 'aristocracy' (PR: \$297), with the monarchic general will appearing as an 'arbitrary power of domination' (PR: §302) embodied by all. ${ }^{7}$ The dissolution of the constitution between the democrats and aristocrats into their respective self-sufficient forms would take place all the while each element believed to embody the general will. Anticipating this approaching debauch, Hegel has no choice but to turn to the roots of political freedom, which however cannot be found in peace and its relations, but only in war.

\section{War and Courage}

Rupert H. Gordon argues that Hegel makes war into a 'test case' (Gordon 2000: 318) for political disposition through which it is placed to the challenge of freedom (2000: 321). Peace presents many doubts about the allegiance of the citizen, which 


\section{Courage and Constitution}

is why for Hegel the 'existence of what is free can be shown only in war' (NR: \$143). During wartime the bourgeois are presented with a choice to either remain a citizen or lose freedom 'from the fear of dying' (PR: \$324). Gordon is correct in pointing out that for Hegel political disposition is a 'distinctly modern virtue' (Gordon 2000: 329), for it presupposes rational habituation based on subjective freedom. However, its passage in war toward 'valour [Tapferkeit]' (PR: \$327 reveals an ancient argument in place.

By raising political disposition to the level of valour it attains the force of a 'universal duty' (PR: $\$ 325$, whereby the 'pious phrase' on the 'vanity of temporal things [Dinge] and temporal goods' is restored in its 'significance' (PR: 361). By revealing the evanescence of temporal things in the spectre of war, the state reaffirms itself as the 'absolute power on earth' (PR: 366), reinstating itself as the ultimate aim of individual volition. The fear of wartime death must be overcome by terror before loss of freedom, inviting courage to restore the crumbling purposiveness of the state. Citizens are tasked to prove their fidelity to the general will by a call to 'sacrifice' of their particularity, of their 'life and property, as well as their opinions and all that naturally falls within the province of life' (PR: 360). By being raised to the level of valour (Tapferkeit) (PR: 364) the 'trust' and 'certainty' of political disposition enact an 'external and actual negation of 'all particular ends' (PR: 364). The bourgeois must prove their devotion to the principles that sustain their particular interests through their sacrifice, in a state of nature and faced against another state. The proof of this devotion is contained in the confrontation with death, where the ancient argument takes over, namely that if they allow themselves to be subjugated by this fear, they are by definition a slave. ${ }^{8}$

According to Gordon, Hegel understands valour not in terms of ancient warrior virtue or thymos, but as a modern, 'formal virtue' and 'highest abstraction of freedom from all particular ends' (PR: $\$ 327,364)$, for not 'personal courage but integration with the universal is the important factor' (PR: \$327). This should distinguish modern valour from its ancient, 'heroic' and personalistic counterpart. However, the principle of integration is not exclusively a modern principle, for it was an essential feature of ancient valour as well. Hegel uses similar words in the Philosophy of History when writing on 'Roman virtus', which is 'valor; not, however, the merely personal, but that which is essentially connected with a union of associates; which union is regarded as the supreme interest' (PH: 302/346). He thus echoes Polybius's observation of wartime operation of the republican mixed constitution. ${ }^{9}$ Hegel does, however, subordinate this virtue to the modern principle of rationality, since 'only a positive end and content can give significance to such courage' (PR: \$328). Gordon is thus correct to point out that valour is significant only when it is in the service of 'fully developed reason' (PR: $\$ 273 \mathrm{~A})$. The threatening conflicts between private wills and the mutual exploitation of bourgeois must be halted through fortification of rational relations between the citizens, 


\section{George Hristov}

achieved in conditions of war. But by integrating Roman virtue as the principle of his own state, Hegel still aspires to a form of piety and trust that would carry the strength of ancient conviction, albeit now rationally founded and organized.

This becomes more evident in relation to the agent who performs the call to virtue. The restoration of mutual trust in courage is the sole prerogative of the monarch, who brings the democratic and aristocratic elements together, fostering 'the disposition to act in close association with others' (PR: $\$ 327 \mathrm{~A})$. While the peacetime monarch remains limited by the mediating effects of the estates and the government, in war, they are unconstrained by the formalities of peace:

The outward orientation of the state derives from the fact that it is an individual subject. Its relationship with other states therefore comes under the power of the sovereign, who therefore has direct and sole responsibility for the command of the armed forces, for the conduct of relations with other states through ambassadors etc., and for making war and peace and concluding treaties of other kinds. (PR: §329)

The power of the wartime monarch, as Thom Brooks argues, is 'both great and relatively unchecked' (Brooks 2007: 116) because the limitations placed on internal sovereignty by other institutions are suspended during war. This is done, Brooks further claims, not in order to institute a capricious dictatorship of one person. Instead, by granting the monarch greatly expanded powers, he argues that Hegel seeks to achieve the opposite, for the monarch is the one who 'is most likely to pursue rational ends, rather than its particular passions' (Brooks 2007: 117). Hegel does believe that it is justifiable in wartime 'to transfer more power to a single individual' (NR: \$143). However, this single individual is not a despot presiding over the others. The monarch, being a person of supreme virtue, is the union of the individual will and the authority of the state. Their disposition must as such be embodied by all citizens. Being a free-born and natural citizen of the state, they serve in war as the one in whom complete trust may be placed. Their position remains incorruptible in a condition of 'lengthy period of peace', and among a bourgeois people whose 'coffers are full' (NR: \$162). By assuming the guise of an ancient dictator, they invoke the terrors of wartime death and subjugation, compelling the two estates into freedom. But unlike an ancient dictator, who reimposes an external union, the modern monarch invites sacrifice which does not simply consume the individual, but calls on them to purify their will, identify with political authority and renounce everything which is not of the state. Presenting the citizen with the terrors of freedom lost, they subdue the bourgeois within, and guide them to confidence gained by victory over fear of death. By inciting valour, the highest form of mutual trust, war thus washes away the hypocrisies that multiply in times of peace. 


\section{Courage and Constitution}

Courage thus acts as the highest form in which the general will is manifest in the citizen, an idea which Hegel draws on from his youth. According to Harris, in System of Ethical Life, Hegel regards courage as the 'absolute virtue' which makes all other virtues virtuous (EL: 69). The 'Tapferkeit-bourgeois juxtaposition' in his text on Natural Law, according to Laurence Dickey, demonstrates courage as the central spiritual 'energy' (Dickey 1987: 226) capable of transforming the natural existence of a human being into an ethical and political union. 'Tapferkeit comes into play precisely at the point at which men were obliged for ethico-politico-religious reasons to move beyond the realm of nature' (1987: 226). From mid-1790s Hegel regarded courage as the key to this 'conversion' (1987: 223). In the Philosophy of Right, however, courage is not the originating or the permanent dispositional state in which the citizens find themselves, but acts as a cyclical reaffirmation of the union. Cristi's question on how far Hegel's monarch is removed from Schmittian decisionism (Cristi 1983: 615) can be answered with: quite a lot. The people are not instituted through the individual act of the sovereign, but restored. The monarch does not create a novel constitution, but preserves an existing peacetime constitution. They protect an already present 'system of mediation' (PR: \$302A) into which they themselves are integrated during peacetime. Although courage provides the community with the force of a state, its material roots are still found in modern recognition relations.

By tying courage to an existing system of recognition, Hegel aspires to prevent its decay into self-deception and fanaticism. This is what he saw in the Jacobin dictatorship, which sought to institute a novel order out of virtuous deeds and would indeed come to inspire Schmitt as the first example of sovereign dictatorship. But what Jacobinism also taught Hegel is that the material basis of recognition cannot be found in the contract, for precisely the revolutionaries exemplified an attempt to deduce society out of abstract axioms (PR: \$258). Influenced by Rousseau, Robespierre relied on the originating act of the community in a wartime state of nature. He aimed legislation at warring individuals and at the disposition of atomized bourgeois, in other words, at civil society as a state of nature, attempting to convert it into a realm of virtue (PR: \$258). Courage and all the institutions of the state were to be forged from within the relations of these individual wills. However, all the doubts and mistrusts, which the contract presupposes and against which it aspires to guard against, became exacerbated during the Terror that was unleashed. The alienated bourgeois, lacking objective ties, instead of turning citizen, triggered a bloody orgy of self-delusion, backstabbing and mutual destruction. The hypocrisy that took root in this event was without precedent in history. Succumbing to alienated disposition, their patriotism was vacuous, the virtue that they proclaimed merely 'subjective' (PH: 470/533) while the general will remained an abstraction, all decisions being made 'on the basis of subjective representations $[\ldots]$ of opinion and the caprice of the arbitrary will' (PR: \$270). 


\section{George Hristov}

Consumed by the experience of death (PS: 361/438) the would-be tyrant-slayers were reduced to the Hobbesian solitary individual. The contractual parties turned against each other and valour became no more than fanatical self-deception, while the people became a black hole into which everything was consumed. The democratic element-the revolutionary masses-remained without respective organization and were swallowed by the aristocratic estatethe party - which in turn could present itself as nothing more but a 'victorious faction' (PS: 360/437) usurping the government. The monarchic element-the revolutionary leader-devoured the party in turn, appearing as a tyrant monopolizing the general will (PS: 359/435).

Thus, Robespierre's 'despotism of liberty', instead of fashioning a bulwark against tyranny, made dictatorship synonymous with it. Alarmed by this spectacle Hegel takes his cue from the legislators of antiquity, who worked not on the disposition of atomized individuals, but on tribes and clans, in other words, on existing systems of families, as a result of which both recognition and courage had material roots in an immediate form of trust and love. These roots still find their home for Hegel in familial relations (PR: \$169), which is why political disposition as well as courage, itself a form of trust, can rely on more than a mere contract. Hegel's bourgeois appears in a state of nature against other individuals only within a constituted political state, as citizens within civil society, where contracts may be perpetuated safely and mutual mistrust held in check. But more importantly, as citizens they appear in a state of nature in the form of an existing political order against another state, which in turn cannot be established by a contract.

Certainly, the political state in Hegel's eyes still draws its powers on the conditions found in the state of nature. Hegel's monarchy, like Hobbes's Leviathan, presupposes war. Both contract and courage as their respective foundations emerge from wartime fear encountered in the natural state. But contract can found only civil society, which remains permeated by mistrust, and is for Hegel no more than a continuation of the Hobbesian natural state now presided over by coercive authority. Devoid of either this coercive authority or internal organization provided by the state, it becomes a space where suspicion and the fear of death persist in an elevated form, such was the case during the Jacobin terror.

Courage, the overcoming of the natural fear of death and the intensification of mutual trust, does serve as the basis for political union. But since it relies on existing relations of trust, the fear encountered in the state of nature for Hegel cannot be natural but must be already socially mediated political fear. The wartime terror in a state of nature is not the fear of a Hobbesian solitary bourgeois faced with the anticipation of death, but the experience of the citizen threatened with loss of political independence. The response to fear is thus not consent and submission as an individual act of self-preservation, but collective conviction and sacrifice of individuality in order to preserve freedom. Hegel still holds fast to the ancient maxim 


\section{Courage and Constitution}

that a citizen must be 'accustomed to fearing slavery more than death' (Plato, Republic, 387b).

\section{Three wars}

For war to be effective as a source of citizen virtue, Hegel requires a corresponding international order. Although Hegel, in so far as his philosophy comprehends ' $w$ hat is' (PR: Preface), presents the Westphalian order of his day, Andrew Buchwalter is correct to point out that it is wrong to suggest that he merely reaffirms the Hobbesian account of interstate relations' (Buchwalter 2012: 213). Hegel does not view relations between states only on 'exclusionary terms' (2012: 213). He does endorse the standpoint that 'one state should not interfere with the affairs of another' (PR: §351), but he extends this into mutual dependency of states as constitutive for their respective citizenships. Recognition between states as individual sovereigns is foundational for their diplomatic autonomy, but also for citizen's political disposition (Buchwalter 2012: 214-15). The dependency of citizen's disposition on an external, anarchic international order then comes to mirror the ancient world. In one instance, Hegel regards relations between modern states as analogous to ancient Greek hegemony: 'The trend of the states $[\ldots]$ is toward uniformity $[\ldots]$ which parallels the idea of hegemony in Greece, except that now it is the hegemony of spirit' (quoted in Avineri 1972: 207). However, the absence of a political hegemon allows him to advocate for the autarkeia of the nation-state in line with pre-hegemonic antiquity. The uniformity in Greece, enforced by a political hegemon, lead to the loss of independence of the polis, while in modern Europe the hegemony of reason allows for the simultaneous preservation of the state's self-sufficiency.

The relations between self-sufficient wholes are established within a family of 'European nations' (PR: §339A), a system of states on an equal footing of spiritual development. The family is juxtaposed to 'barbarians' (PR: \$351), which also mirrors the Greek distinction of the same kind. This division entailed different kinds of wars. Like in pre-imperial Greece and Italy, a set of unwritten customs within a specified family of nations guides how wars will be waged. Examples of ancient war rites included honouring and returning the bodies of enemies, not attacking during religious festivals, respecting ambassadors and priests of enemy states, as well as not destroying sacred buildings or objects (Lanni 2008: 477-79). For the Greeks, these rites were religious, based on shared customs, gods and language, primarily in place for 'protecting sacred objects and observances', and did not necessarily 'encompass humanitarian ideals' (2008: 470). In Hegel's case, the 'universal principle' of 'legislation, customs, and culture [Bildung]' (PR: §339A) that modern states share does encompass humanitarian principles, the sacred which should not be touched by war being the private life of the citizens and the 


\section{George Hristov}

institutions of civil society. Modern wars will 'on no account be waged either on internal institutions and the peace of private and family life, or on private individuals' (PR: §338).

Owing to this common principle, war between modern states is limited in its destructiveness. Endowed with European values states would extend each other respect in war by observing the same principles that animate them in peace. These wars would be conducted in a 'humane manner', where combatants would not face each other in 'hatred' (PR: \$338). Warring citizens would treat each other as citizens by performing a 'duty' (PR: \$338) toward their own state. This mutual respect cannot be extended to 'barbarians', since they do not share in common reason. 'Civilized nations' are entitled 'to regard and treat as barbarians other nations which are less advanced than they are in the substantial moments of the state' (PR: §338).

However, colonialism, in distinction to its ancient counterpart, which was a state project from the outset, has its source in civil society and the desire of the bourgeois for further expansion of the market (PR: \$248A). Wars emerging from colonialism do not have as their paramount purpose the state as spiritual unity, but stand in service of capital and contractual relations. The expansion of the market threatens to disorganize states as self-sufficient 'wholes which can satisfy their own needs internally' (PR: §332). By exciting the passions of the bourgeois, colonial wars would follow in this trajectory and may even deepen the state's subordination to the discipline of civil society. The state's means of sustaining its self-sufficiency would now be weaponized by commercial expansion. Furthermore, a modern state facing a colonial prey would have a hard time invoking the fear of death and loss of freedom in the citizens. The essential precondition for the sacrifice of particularity — terror before the nullification of right—would be absent. The state must 'generate opposition and create an enemy' (PR: \$324A), but if the enemy is to awaken the feeling which is the source of political virtue, its opposition must be relative to the power of Hegel's state, in other words, the contest must be a competitive one. Such a contest then can take place only within the boundary of 'civilized states'. Consequently, although colonial wars provide 'significance for world history' (PR: \$351) by provoking a struggle for recognition between the conqueror and the conquered, they are inadequate for maintaining citizen virtue.

However, the limited war of virtue within the European family succumbs to this problem as well. Hegel's whole argument for the significance of valour as a condition of citizenship rests on counter-examples where the people make themselves 'prey for other peoples' by sinking into private life (NR: \$303), where lack of internal sovereignty leads to 'subjugation by others', as well as the inability of states to survive if their independence is not guaranteed by 'armed strength' (PR: \$324). But he then demonstrates that these threats tend to dissipate in modernity. Giving the example of the Messenian disaster, where the Spartans enslaved all of those 


\section{Courage and Constitution}

who did not emigrate from their homeland, Hegel argues that 'there are fewer and fewer such internecine wars because there is a more highly developed being-for-self of families and individuals' (NR: \$163). The unity of the state being 'weaker' in modernity 'there is no danger for the totality of rights and institutions, for religion, education' (NR: \$163) in a war between civilized states. Indeed, a war between states 'in whom civil society has developed' (NR: \$163), leads to a situation in which no one will 'take it so much to heart if a part or province is incorporated into another state, since those who pass over retain their rights, religion' (NR: \$163). Owing to their uniformity, modern states appear to be interchangeable from the perspective of the bourgeois, in the same way that on account of rights, the citizens themselves present a homogeneous material for the states.

Ancient wars, though limited with respect to religious observances, could place whole populations and states under threat of destruction. Slavery was an ever-present danger and consequence of defeat. Although Hegel does not view such threats as credible in modernity, what remains at stake is political independence of the modern state. Through loss of political freedom and the state's selfsufficiency, the citizens would be outstripped of their citizenship. They would turn into mere members of civil society and reduced to precisely those relations that would make them into means of each other, as well as of the conquering state. The only instance where this becomes evident however is total war. Where there is no longer any possibility of peace, where the independence of one of the peoples is threatened, it becomes a war whose sole aim is mutual destruction' (NR: \$163). Thus, if war is to regenerate freedom, awaken virtue and the will to overcome death, it must become total. This war would ensure the mobilization of the whole, whereby the 'entire state has thus become an armed power and is wrenched away from its own internal life to act on an external front' (PR: \$326). In this manner, 'the war of defence' will become 'a war of conquest' (PR: \$326), compelling the state to assume a despotic guise against an external tyrant. And in a struggle against the tyrant, where freedom is threatened, enmity would take on another level, 'mutual destruction' would ensue in which there could be no observance of the principle of humanity. Yet precisely because of this heightened enmity, total war could endanger civil society. The contest would threaten the breakdown of the 'European family'. Reason, the monotheistic hegemon of Europe, would be undermined by injuring the common principle that animates modern states. In seeking to preserve ancient freedom, its modern counterpart would be in danger of being lost.

The impasse, which Hegel's political philosophy encounters, is complicated by the fact that in as much as war might be utilized as a means against decadence, it would not be safe from it. Colonial wars already exemplify this, being driven by bourgeois interests. Limited war has a high potential for decadence, because a call to virtue in such a war could appear cynical without an actual threat of loss of 


\section{George Hristov}

freedom and nullification of right. The citizens would be unstuck from their 'ways' (PR: \$324) after a long peace, but without plausible consequences, the test would appear fake, and war itself pointlessly detrimental to existing commercial ties, something Hegel considers as well (on this ambivalence, see Jaeger 2002: 514). Total war-farthest removed from decadence-presupposes a campaign of mutual destruction of competing social orders, something the bourgeois are not good at, because as the Jacobins have shown, they end up destroying themselves.

During prolonged peace that would precede all these wars, hypocrisy veils the disposition of the citizens. Whichever war the monarch would use to suspend peace, they could not know if the citizens are in fact still citizens or not. The bourgeois would be like Schrödinger's cat, the monarch would find out what is inside the box only by opening it, discovering either virtuous citizens, or indeed hypocrites and slaves. Ancient families, which were tied to each other, cultivated from birth objectively transmitted dispositions that acted, as Hegel argues by referring to Plato, as 'the principle of the State' (PH: 469/531). He does tie modern political disposition to a system of families, but they, being atomized, still generate individuals that embody a subjective will, which is why "we have no guarantee that the will in question has that right disposition which is essential to the stability of the State' (PH: 469/531). Political authority will always have to wonder whether 'pious phrases' finally lost their significance. In the case that citizens already turned mere bourgeois, dictatorship and war would be compromised. Sacrifice, ancient cruelties and terrors, would become devoid of virtue, while modern self-deceptions and hypocrisies would be bolstered with terrifying violence. Just like with the Jacobins, the sanguine but virtuous violence of the citizen would become polluted by the cynical and dishonest cruelty of the bourgeois. Instead of bringing together the best of the two worlds, Hegel's monarch would end up with the worst of both. This would realize Nietzsche's criticism, who as a 'niche' decadent (Nietzsche 2005: 76) scorned 'complete decadents' for believing that they can 'extricate themselves from decadence by waging war on it', when 'what they choose as a remedy, as an escape, is itself only another expression of decadence' (2005: 166). War became harbinger of decadence even in antiquity. The Third Punic War, like the Peloponnesian War that Polybius saw as the precedent for the former (Polybius 1968: 369), announced the end of the age of virtue and the onset of the hegemons. If the ancients managed to botch everything, the bourgeois-citizen stands no chance of perpetuating either war or dictatorship as vehicles of freedom.

Lacking a viable war, Hegel's constitution is destined for dissolution. The absence of a war that would awaken the conviction for freedom necessary to overcome the fear of the death, places the democrats and aristocrats toward a trajectory of private life and mutual enslavement. With the monarch's wartime impotence, Hegel's political philosophy thus becomes an inadequate expression of freedom. 


\section{Courage and Constitution}

\section{George Hristov \\ Universität Regensburg, Germany \\ george.hristov@gmail.com}

\section{Notes}

${ }^{1}$ Abbreviations used:

EL = Hegel, System of Ethical Life and First Philosophy of Spirit, trans. H. S. Harris and T. M. Knox (Albany: State University of New York Press, 1979).

NL = Hegel, Natural Law: The Scientific Ways of Treating Natural Law, Its Place in Moral Philosophy, and Its Relation to the Positive Sciences of Law, trans. T. M. Knox (Philadelphia: University of Pennsylvania Press, 1975).

NR = Hegel, Lectures on Natural Right and Political Science: The First Philosophy of Right, trans. J. M. Stewart and P. C. Hodgson (Berkeley: University of California Press, 1995).

PH = Hegel, The Philosophy of History, trans. J. Sibree (Kitchener: Batoche Books, 2001)/ Vorlesungen über die Philosophie der Geschichte, Werke Bd. 12 (Frankfurt: Suhrkamp, 1989).

PR = Hegel, Elements of the Philosophy of Right, trans. H. B. Nisbet (Cambridge: Cambridge University Press, 1991)/Grundlinien der Philosophie des Rechts oder Naturrecht und Staatswissenschaft im Grundrisse, Werke Bd. 7 (Frankfurt: Suhrkamp, 1989).

PS = Hegel, Phenomenology of Spirit, trans. A. V. Miller (Oxford: Oxford University Press, 1977)/Phänomenologie des Geistes, Werke Bd. 3 (Frankfurt: Suhrkamp, 1989).

$T W=$ Hegel, Early Theological Writings, trans. T. M. Knox (Philadelphia: University of Pennsylvania Press. 1996).

2 Although Polybius writes on a procession of regimes within a single state, while Hegel takes the concept of regimes to signify different ages of history and distinct states, the single idea of the state is still the protagonist of Hegel's world history. In this regard, the regimes of history are still regimes of the state as such, or rather the 'unfolding' of Spirit which remains 'one and the same' (PH: 24/74). This is why, as I will show in the following, Hegel's modern monarchy is not a wholly novel regime, but the synthesis of the historical regimes of the idea of the state.

${ }^{3}$ Wallbank writes that the 'mixed constitution' in the prime of the Roman Republic still relied on the 'predominance' of the aristocratic element or the senate (Wallbank 1943: 82). During peacetime, Hegel's state also relies chiefly on the political activity of the aristocrats, who run the machinery of the state.

${ }^{4}$ Terry Pinkard argues that the continual Roman adherence to despotic power or political authority 'backed up by force' is what made Hegel regard 'the move from "Republic" to "Empire" as not involving 'any great change in Roman political psychology' (Pinkard 2017: 83). Certainly, Hegel does think that there is continuity in a Roman 'prosaic' (PH: 310/354) view of religion, which 


\section{George Hristov}

always remained in service to political power. However, it is precisely in the service to this despotic and divine authority that the 'republican's whole soul' remained 'in the republic' and could through sacrifice participate in its 'immortality' (TW: 156-57). The Empire, on the other hand, gave the citizen 'only a right to the security of that property which now filled his entire world', while death, 'the phenomenon which demolished the whole structure of his purposes and the activity of his entire life, must have become something terrifying, since nothing survived him' (TW: 157). ${ }^{5}$ Hegel's master-slave dialectic from the Phenomenology has this same idea for its background. Preceding the relationship between the master and the slave, two self-consciousnesses find themselves in a kind of a Hobbesian affair of a struggle for life and death, and in a state of war (PS: 113-14/148-49). The transition to a state of peace and work presupposes some kind of arrangement between the two parties, and in any case the failure of one party to overcome the fear of death (PS: 113-14/148-49) and thus their consent to become a slave. The principle behind this process is of course the ancient dictum that 'only through staking one's life' can freedom be 'won' (PS: 114/149).

${ }^{6}$ One point of Hegel's critique of the contractual tradition is that this idea resurrects and inverts the old relations of the state, whereby 'political rights and duties' (PR: \$324) were regarded as private property in opposition to centralized state power. Now, Hegel argues, this centralized power itself is seen as being an object of a contract. The contract theory, according to Hegel, repeats this historical confusion by reverting the relation, since as Herbert Schnädelbach argues, in both cases, state power and private property of the individual are taken as one and the same (Schnädelbach 1987: 117).

7 Things would be even worse than in antiquity. Since Hegel's state preserves not only the spirit of Rome, but that of Athens as well, the inner dimension of conflict would be defined not only by struggles playing out on the vertical axis, between the three estates of the mixed constitution, but by those on the horizontal axis as well, between factions of aristocratic families and their democratic loyalists. The democratic constitution of Athens was 'rent asunder, but only in the way of factions' (PH: 298/340), similar to the late Republic. The horizontal axis of Hegel's state, which includes divisions between corporate formations and their representatives would thus add another dimension to the general decay.

${ }^{8}$ Hegel, while condemning slavery, adheres to its ancient understanding, according to which a slave is made by their cowardice and preference for living in servitude over facing death (Aristotle 1995: 16). He writes that if 'someone is a slave, his own will is responsible, just as the responsibility lies with the will of a people if that people is subjugated. Thus the wrong of slavery is the fault not only of those who enslave or subjugate people, but of the slaves and the subjugated themselves' (PR: \$57A).

${ }^{9}$ One remarkable example of Roman virtue and 'true valour', where one counts as 'one among many' (PR: $\$ 327 \mathrm{~A}$ ) was the sacrifice of his own son performed by the consul and dictator Titus Imperiosus Torquatus. During the Latin wars his son disobeyed the order, issued under penalty of death, that none should leave their post. The son, pursuing glory and demonstrating exceptional valour, took the opportunity to attack and defeat some Latin skirmishers, returning victorious and with abundant spoils, thus breaching the common discipline imposed by the 


\section{Courage and Constitution}

father. Instead of being granted a reward as was customary, he was given to the executioner (Livy 1982, VIII, 5-10).

\section{Bibliography}

Aristotle (1995), Politics, trans. E. Barker. Oxford: Oxford University Press. Avineri, S. (1972), Hegel's Theory of the Modern State. Cambridge: Cambridge University Press.

Brooks, T. (2007), 'No Rubber Stamp: Hegel's Constitutional Monarch', History of Political Thought 28:1: 91-119.

Buchwalter, A. (2012), 'Hegel, Global Justice, and Mutual Recognition', in A. Buchwalter (ed.), Hegel and Global Justice. London and New York: Springer. Cristi, R. (1983), 'The Hegelsche Mitte and Hegel's Monarch', Political Theory 11:4: 601-22.

Cristi, R. (2005), Hegel on Freedom and Authority. Cardiff: University of Wales Press. Dickey, L. (1987), Hegel: Religion Economics Politics: Religion, Economics, and the Politics of Spirit, 1770-1807. Cambridge: Cambridge University Press.

Gordon, H. R. (2000), 'Modernity, Freedom, and the State: Hegel's Concept of Patriotism', The Review of Politics 62:2: 295-325.

Hobbes, T. (1998), Leviathan, ed. J. C. A. Gaskin. Oxford: Oxford University Press. Jaeger, H. (2002), 'Hegel's reluctant realism and the transnationalisation of civil society', Review of International Studies 28: 497-517.

Lanni, A. (2008), 'The Laws of War in Ancient Greece', Law and History Review 26:3: 469-89.

Livy, T. (1982), Rome and Italy: Books VI-X of the History of Rome from Its Foundation, trans. B. Radice. London: Penguin.

Nietzsche, F. (2005), The Anti-Christ, Ecce Homo, Twilight of the Idols and Other Writings, ed. A. Ridley and J. Norman, trans. J. Norman. Cambridge: Cambridge University Press.

Patten, A. (2002), Hegel's Idea of Freedom. Oxford: Oxford University Press.

Pinkard, T. (2017), Does History Make Sense? Hegel on the Historical Shapes of Justice. London: Harvard University Press.

Plato (1991), The Republic of Plato, trans. Allan Bloom. New York: Basic Books. Polybius (1968), The Histories, Volume VI, ed. E. H. Warmington, trans. W. R. Paton. Cambridge: Harvard University Press.

Polybius (1979), The Histories, Volume III, ed. S. D. Olson, trans. S. D. Olson and W. R. Paton. Cambridge: Harvard University Press.

Riley, P. (1973), 'Hegel on Consent and Social-Contract Theory: Does He "Cancel and Preserve" the Will?', The Western Political Quarterly 26:1: 130-61. 


\section{George Hristov}

Sallust (2010), Catiline's Conspiracy, The Jugurthine War, Histories, trans. W. W. Batstone. Oxford: Oxford University Press.

Schnädelbach, H. (1987), 'Hegel und die Vertragstheorie', Hegel-Studien 22: 111-28. Strauss, L. (2019), On Hegel, ed. P. Franco. Chicago: University of Chicago Press. Wallbank, F. W. (1943), 'Polybius on the Roman Constitution', The Classical Quarterly 37:3/4: 73-89.

Wallbank, F. W. (2002), Polybius, Rome and the Hellenistic World. Cambridge: Cambridge University Press. 